\title{
The influence of fertilization on the soil characteristics of a calcareous chernozem in a long term experiment
}

\author{
János Kátai \\ Department of Agrochemistry and Soil Science, Faculty of Agricultural and Food Sciences and Environment Management, \\ Centre of Agriculture and Applied Economic Sciences, University of Debrecen, 138 Böszörményi út, H-4032 Debrecen \\ Email: katai@agr.unideb.hu
}

Keywords: soil characteristics, soil microbes, $\mathrm{pH}$, hydrolytic acidity, acidification, microbial activity

SUMMARY

\begin{abstract}
In the long term fertilization experiment of the University of Debrecen, Centre for Agricultural and Applied Economic Science(CAAEC) (Debrecen Látókép), the effects of a 25-year-long fertilization were examined in terms of some chemical and microbiological properties of soil. With the growing doses of fertilizers, the available nutrient content of soil increased. At the same time the pH significantly decreased, while the hidden acidity increased. Moreover, the ratio between the soil bacteria and microscopic fungi, and the occurrence of microbes also changed. The number of sensitive physiological bacteria groups decreased dramatically. These changes indicate the reactions of living organisms; they correspond to the "resistance stage” of stress effects, but in the case of nitrifying bacteria, they reach the „exhaustion stage".
\end{abstract}

\section{INTRODUCTION}

An important part of plant growing technologies is represented by the nutrient supply of soil. In Hungary the utilization of fertilizers had increased dynamically till the middle of the 1980's (250-300 kg ha $\left.{ }^{-1} \mathrm{NPK}\right)$. Due to the quantity of fertilizers, the yields doubled or tripled compared to the yields in the 1960's (Bocz, 2001). By the end of the 80's, the utilization of fertilizers had decreased drastically (20-50 kg ha-1 NPK), and consequently the yields got halved. After that, a small scale increase could be observed in the utilization of fertilizers, and finally its level stagnated (Pepó - Nagy, 1997). At the beginning of the century the nutrient balance was negative because only half of the nutrient quantity that could be uptake by plants is applied (Sárvári et al., 2002).

The fertilization has direct and indirect effects on the quantitative occurrence and life of soil microorganisms (Virág, 1981). The direct influence of fertilizers is due to their chemical compositions, solubility, quantities and the ratio to other chemicals, while the indirect effect is due to the changed circumstances in soil environment.

According to some papers (Zvyagintsev et al., 1987; Andrejuk, 1990; Kátai et al., 1995) the small and medium doses of fertilizers increased the quantity of soil microbes, while the large doses hampered the living microorganisms in soil (Lásztity et al., 1981; Zvyagintsev, 1987). According to certain scientists (Andrejuk, 1990; Kátai, 1997, 1999) the effect of a moderate dose of fertilizer on the soil biological activity $\left(\mathrm{CO}_{2}\right.$ production, cellulose decomposing activity, and enzymes activity) was stimulating. The sensitive soil microbiological parameters (cellulose decomposing activity, phosphatase activity) were inhibited by large doses of fertilizers (Gulyás, 1985).

Soil degradation processes significantly contribute to the decline of soil fertility according to Várallyay (2006). Among these processes soil acidification was emphasized. Nowadays the subject is topical; several researchers deal with soil acidification (Simon et al., 2006), the kinetics of photolytic processes (Rékási, 2008), and the buffer capacity of soils (Rékási et al., 2007).

Several papers deal with the effects of intensive application of fertilizers. They change soil properties: the $\mathrm{pH}$ decreases compared to the control (Blaskó et al., 1999; Kádár et al., 2007; Füleky, 2008). The other evidence of acidification is the increase of hydrolytic acidity, which proves stronger , hidden acidity" in connection with the colloids. Generally, soil microbiological parameters do not change at once by these effects. The microbes can compensate the effects of soil acidification till the $\mathrm{pH}$ in soil reaches the critical limit. According to Avdonyin (1972) the number of bacteria decreased with the acidification of soil, while the number of fungi increased significantly. Most soil bacteria - e.g. $\mathrm{N}_{2}$-fixing and nitrifying - did not grow when the $\mathrm{pH}$ of soil was under 4.5, except for the sulphur oxidizing ones, which grew under acidic circumstances. There were some mould fungi which were also sensitive to soil acidification.

The three stages of stress (warning reaction, resistance, exhaustion) can be observed in the agricultural ecosystem (Zvyagintsev, 1987). The long lasting stress effects can reach the „resistance stage” in the quantitative dynamics and activity of microbial populations.

Agrotechnical parameters contribute to the sustainability and enhancement of soil fertility, and thus the proper quantity and good quality of yield. At the same time these parameters influence the physical and chemical properties of soil, as well as the occurrence and activity of soil microbes. A long-term experiment is especially adapted to evaluate the cumulative effect of recurrent treatments and the tendency of changes in soil. 
In the long term fertilization experiment in Látókép of UD, CAAEC, the effects of a 25-year-long fertilization were examined in calcareous chernozem soil. In a block fertilized (maize triculture) we studied the effects of different large doses of fertilizer on the physical, chemical and microbial properties of soil. We experienced that fertilization did not only change the $\mathrm{pH}$ and hydrolytic acidity of soil, but also the quantity of microbial groups and the activity of microbiological processes - due to soil acidification as a stress effect. This paper deals with the relevant results.

\section{MATERIALS AND METHODS}

The fertilization experiment was set up in Debrecen-Látókép, the eastern part of Hajdúsági löszhát, on calcareous chernozem [according to WRB 2006: Calcic Endofluvic Chernozem (Endosceletic)] 27 years ago, in 1983. In this paper some physical, chemical and microbiological soil properties are presented in different fertilization treatments of maize triculture without irrigation, and the results reflect the stress stages of soil. (The treatments were as follows: 1. control (0), 2. small $\left(\mathrm{N}_{60} \mathrm{P}_{45} \mathrm{~K}_{45}\right)$, 3. small-medium $\left(\mathrm{N}_{120} \mathrm{P}_{90} \mathrm{~K}_{90}\right)$, 4. medium-large $\left(\mathrm{N}_{180} \mathrm{P}_{135} \mathrm{~K}_{135}\right)$, and 5. large doses $\left(\mathrm{N}_{240} \mathrm{P}_{180} \mathrm{~K}_{180}\right)$. The plant order of the triculture was maize-pea-winter wheat.

Among the physical properties, the moisture content was measured by drying the soil at $105^{\circ} \mathrm{C}$, the silt and clay fractions were measured by settling method, the plasticity index was determined according to Arany. The $\mathrm{pH}$ of soil was measured in distilled water and $1 \mathrm{M} \mathrm{KCl}$, and the hydrolytic acidity according to Buzás (1988). The organic carbon and nitrogen contents (TYURIN cit. FILEP, 1988), the AL soluble phosphorus and potassium contents (GEREI, 1970), and the nitrate content (FELFÖLDY, 1987) of soil were determined.

The total numbers of bacteria (bouillon agar) and fungi (PGA) were measured by plate dilution method (Szegi, 1979), the numbers of nitrifying and cellulose decomposing bacteria were measured according to the method for „the most probable germ number” (Pochon - Tardieux, 1962). The measurement of phosphatase activity was carried out according to Krámer-Erdei (cit. Szegi, 1979), and the activity of saccharase by the method of Frankenberger et al., (1983). The catalase activity was measured by gasometrical method, while urease activity (Szegi, 1979) was based on the quantitative determination of ammonia which released from the urea. The dehydrogenase enzyme activity was measured by Mersi (1996), when the INT (2-(p-iodophenyl)-3-(pnitrophenil)-5-phenil tetrazolium chloride) reduced to INTF (iodonitro-tetrazolium formazan).

Soil samples were taken twice (in July and September), the measurements were carried out in four repetitions, and the data were statistically evaluated by Microsoft Excel software.

\section{RESULTS AND DISCUSSION}

The effects of different treatments on the physical, chemical and microbiological properties of soil are shown in Tables 1-5.

Among the physical properties (Table 1) the moisture content, the quantity of silt and clay fraction and the plasticity index were the most important ones examined. There were no significant differences between the treatments regarding these three soil parameters. The moisture content of soil was 17.58-19.82 \% at the first sampling time, and between 20.19-21.96 \% at the second sampling time. These moisture contents could be regarded as remarkable. The silt and clay contents in the treatments were between 50.48- 56.44 \%, and the Arany-type plasticity index was 37-39. According to the last two parameters the soil had loam texture.

The most important physical features of the treated soils (Debrecen - Látókép, 2008)

\begin{tabular}{|c|c|c|c|c|}
\hline \multicolumn{2}{|c|}{ Treatments } & $\begin{array}{c}\text { Moisture } \\
\text { content }\end{array}$ & $\begin{array}{c}\text { Silt and clay } \\
\text { fraction }\end{array}$ & $\begin{array}{c}\text { Plasticity } \\
\text { according to } \\
\text { Arany }\end{array}$ \\
\hline \hline \multirow{2}{*}{1} & July & 19.68 & 55.32 & 37.0 \\
\cline { 2 - 5 } & September & 21.21 & 52.44 & 38.0 \\
\hline \multirow{2}{*}{2} & July & 19.82 & 53.20 & 37.0 \\
\cline { 2 - 6 } & September & 21.96 & 54.72 & 37.0 \\
\hline \multirow{2}{*}{3} & July & 17.58 & 53.12 & 38.0 \\
\cline { 2 - 6 } & September & 21.15 & 52.88 & 37.0 \\
\hline \multirow{2}{*}{4} & July & 17.99 & 54.56 & 37.0 \\
\cline { 2 - 6 } & September & 21.88 & 56.44 & 38.0 \\
\hline \multirow{2}{*}{5} & July & 18.66 & 52.48 & 37.0 \\
\cline { 2 - 6 } & September & 20.19 & 50.48 & 39.0 \\
\hline \multirow{2}{*}{ LSD $5 \%$} & 0.618 & 1.17 & 0.588 \\
\hline \multirow{2}{*}{ Variance analysis } & $\begin{array}{c}\text { F-ratio } \\
\text { 8.03*** }\end{array}$ & $\begin{array}{c}\text { F-ratio } \\
\mathbf{9 . 0 5} * * *\end{array}$ & $\mathbf{F}-$ ratio \\
\hline
\end{tabular}


The increasing doses of fertilizers significantly decreased the $\mathrm{pH}_{\mathrm{H} 2 \mathrm{O}}$ (from 6.43 to 5.74 in July and from 6.41 to 5.65 in September) in all treatments. The results are presented in Table 2. The rate of decrease was in close correlation with the quantities of fertilizer applied. The regularly applied fertilizers decreased the $\mathrm{pH}$ by 0.69 0.76. In the case of $\mathrm{pH}_{\mathrm{KCl}}$ the figures revealed a similar tendency as with $\mathrm{pH}_{\mathrm{H} 2 \mathrm{O}}$, except for treatment 2 . A significant reduction was measured between the treatments compared to the control. Due to the large doses of fertilizers regularly applied, the $\mathrm{pH}$ decreased by 0.52 and 0.68 .

The effects of fertilization on the pH and the hydrolytic acidity $\left(\mathrm{y}_{1}\right)$ of soil (Debrecen - Látókép, 2008)

\begin{tabular}{|c|c|c|c|c|}
\hline Treatments & & $\mathrm{pH}_{\mathrm{H} 2 \mathrm{O}}$ & $\mathrm{pH}_{\mathrm{KCl}}$ & $\mathrm{y}_{1}$ \\
\hline \multirow{2}{*}{1} & July & 6.43 & 4.93 & 9.91 \\
\hline & September & 6.41 & 5.02 & 9.29 \\
\hline \multirow{2}{*}{2} & July & 6.25 & 4.86 & 12.06 \\
\hline & \begin{tabular}{|l|} 
September \\
\end{tabular} & 6.24 & 4.87 & 10.36 \\
\hline \multirow{2}{*}{3} & July & 6.02 & 4.72 & 18.29 \\
\hline & September & 5.94 & 4.65 & 13.67 \\
\hline \multirow{2}{*}{4} & July & 5.81 & 4.46 & 19.51 \\
\hline & September & 5.75 & 4.46 & 14.97 \\
\hline \multirow{2}{*}{5} & July & 5.74 & 4.41 & 22.73 \\
\hline & September & 5.65 & 4.34 & 18.01 \\
\hline \multicolumn{2}{|c|}{$\mathrm{LSD}_{5 \%}$} & 0.115 & 0.100 & 1.934 \\
\hline \multicolumn{2}{|c|}{ Variance analysis } & $\begin{array}{l}\text { F-ratio } \\
45.87 * * *\end{array}$ & $\begin{array}{l}\text { F-ratio } \\
41.08 * * *\end{array}$ & $\begin{array}{l}\text { F-ratio } \\
35.95 * * *\end{array}$ \\
\hline
\end{tabular}

It is very important to highlight that large differences were found between the two $\mathrm{pH}$ values. The differences ranged between 1.29-1.47, which implied that the measurement of hydrolytic acidity provided more information about the state of soil. The hydrolytic acidity increased significantly except for treatment 2 . With the increasing doses of fertilizers the hydrolytic acidity also increased by the same ratio. Similar results had been obtained in earlier measurements, but the differences between the treatments had been smaller (Kátai, 2006).

The nutrient stock of soil can be evaluated with the organic carbon, or rather the calculated humus content. In spite of the different treatments, there were no significant differences in the organic carbon contents (1.13-1.27 $\%)$. Regarding the AL-soluble phosphorus content, it was about $100 \mathrm{mg} \cdot \mathrm{kg}^{-1}$ in the control, but it increased to $238 \mathrm{mg} \cdot \mathrm{kg}^{-1}$ in the large dose treatment in July. The extent of the increase depended on the doses. In September some differences could be observed between the treatments, but smaller quantities of AL-phosphorus were measured (35.74- $174.7 \mathrm{mg} \cdot \mathrm{kg}^{-1}$ ).

The effects of fertilization on the nutrient content parameters of soils (Debrecen - Látókép, 2008)

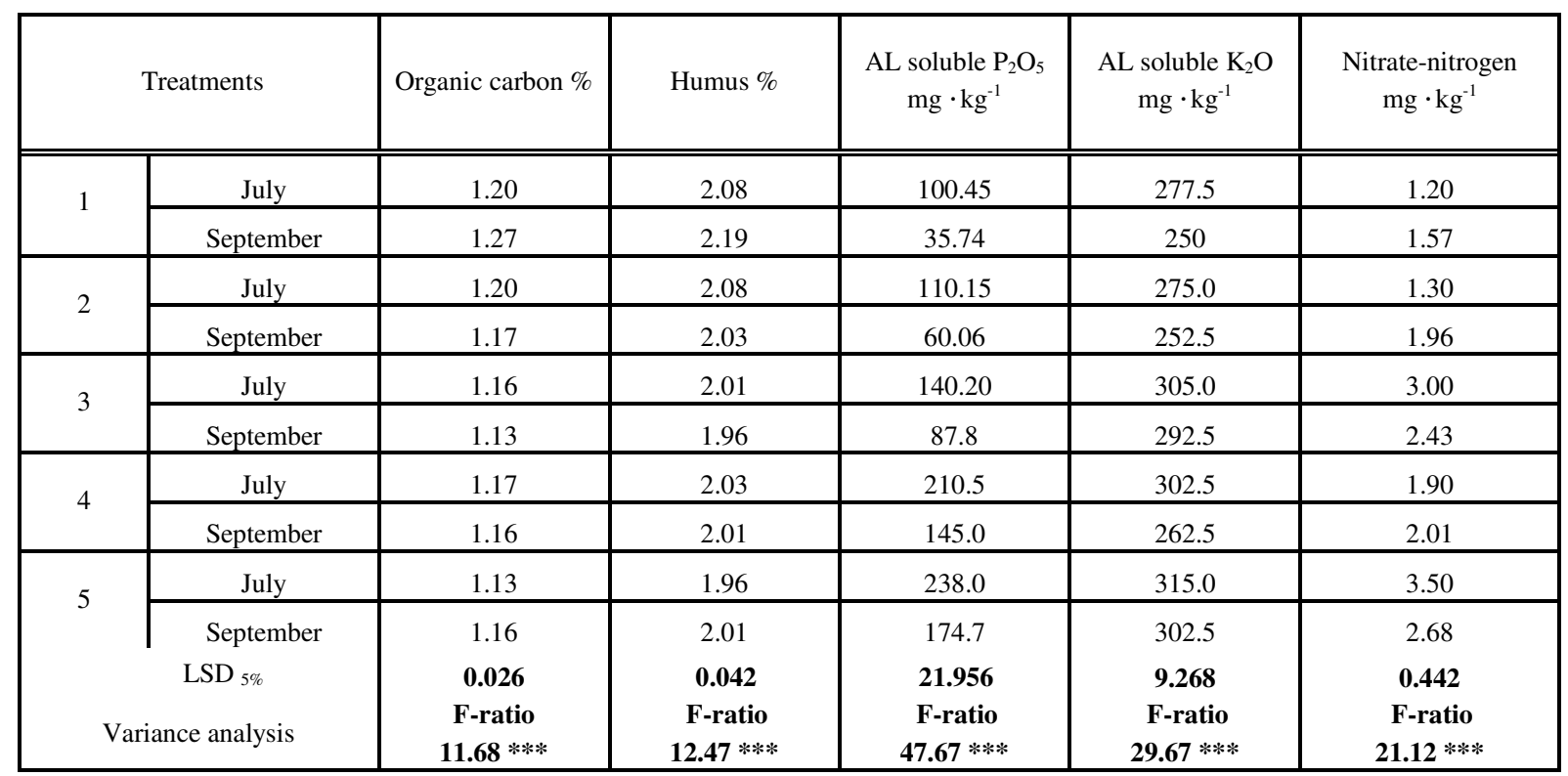


The effects of different doses of fertilizer can be proven in terms of the AL-soluble potassium content of soil. Similarly to the results of phosphorus, lower values were measured at the second sampling time (in July: 277.5$315 \mathrm{~K}_{2} \mathrm{O} \mathrm{mg} \cdot \mathrm{kg}^{-1}$, in August: $250-302.5 \mathrm{~K}_{2} \mathrm{O} \mathrm{mg} \cdot \mathrm{kg}^{-1}$ ). The $\mathrm{NO}_{3}-\mathrm{N}$ content of soil was relatively low (1.2-3.5 $\mathrm{NO}_{3}-\mathrm{N} \mathrm{mg} \cdot \mathrm{kg}^{-1}$ ), but this value increased with the increasing doses.

Based on our results, it is evident that - with the proper moisture content - the nutrient uptake of plants was tremendous between July and September. At the same time, the effects of the treatments were unambiguous (Table 3).

The effects of the treatments on the quantity and ratio of soil bacteria and fungi, as well as on the quantity occurrences of nitrifying and cellulose decomposing bacteria are shown in Table 4. The number of total bacteria decreased significantly in the treatments 3,4 and 5, while the number of fungi increased significantly in treatments 4 and 5. The ratio of the quantities of bacteria and fungi changed dramatically. In the control it was 200 , but with the large doses of fertilizers this ratio decreased to about 50 . The decreasing number of cellulose decomposing bacteria was striking. Regarding the nitrifying bacteria, very few were found and later they disappeared from the soil because of the stress effect. This meant the „exhaustion stage”. On the basis of our results from 1999 and 2000, a small scale stimulating effect was observed (Kátai, 2006).

The effects of fertilization on the amount of microorganisms and the ratio of bacteria and fungi in the soil

(Debrecen - Látókép, 2008)

\begin{tabular}{|c|c|c|c|c|c|c|}
\hline \multicolumn{2}{|c|}{ Treatments } & \multirow{2}{*}{$\begin{array}{c}\begin{array}{c}\text { Bacteria } \times 10^{5} \mathrm{cfu} . \\
\mathrm{g}^{-1} \mathrm{dwt} \text { soil }\end{array} \\
62.0\end{array}$} & \multirow{2}{*}{$\begin{array}{c}\begin{array}{c}\text { Microscopic fungi } \times 10^{3} \\
\text { cfu } \cdot \mathrm{g}^{-1} \mathrm{dwt} \text { soil }\end{array} \\
25.3\end{array}$} & \multirow{2}{*}{$\begin{array}{c}\begin{array}{c}\text { Ratio Bacteria } \\
\text { fungi }\end{array} \\
246\end{array}$} & \multirow{2}{*}{$\begin{array}{c}\begin{array}{c}\text { Number of cellulose } \\
\text { decomposing bacteria } \times 10^{3} \\
\mathrm{cfu} \cdot \mathrm{g}^{-1} \mathrm{dwt} \text { soil }\end{array} \\
6.2\end{array}$} & \multirow{2}{*}{\begin{tabular}{|c|}
$\begin{array}{c}\text { Number of nitrifying } \\
\text { bacteria } \times 10^{3} \mathrm{cfu} \cdot \mathrm{g}^{-1} \\
\mathrm{dwt} \text { soil }\end{array}$ \\
4.8 \\
\end{tabular}} \\
\hline 1 & July & & & & & \\
\hline 1 & September & 64.0 & 28.0 & 229 & 4.4 & 2.1 \\
\hline \multirow{2}{*}{2} & July & 62.3 & 50.5 & 123 & 3.9 & 1.8 \\
\hline & September & 35.0 & 38.3 & 92 & 3.4 & 1.7 \\
\hline \multirow{2}{*}{3} & July & 28.0 & 27.5 & 102 & 2.0 & 2.1 \\
\hline & September & 51.3 & 29.5 & 174 & 2.9 & 1.8 \\
\hline \multirow{2}{*}{4} & July & 31.0 & 66.8 & 46 & 1.7 & 1.0 \\
\hline & September & 32.8 & 47.8 & 69 & 1.5 & 1.0 \\
\hline \multirow{2}{*}{5} & July & 42.3 & 84.8 & 50 & 2.2 & 0.3 \\
\hline & September & 18.3 & 58.5 & 31 & 2.3 & 0.8 \\
\hline & $\mathrm{LSD}_{5 \%}$ & 10.117 & 14.785 & & 1.514 & 1.375 \\
\hline & $\begin{array}{l}\text { Variance } \\
\text { analysis }\end{array}$ & $\begin{array}{r}\text { F-ratio } \\
8.78 * * * \\
\end{array}$ & $\begin{array}{c}\text { F-ratio } \\
11.65 * * *\end{array}$ & & $\begin{array}{c}\text { F-ratio } \\
6.29 * * * \\
\end{array}$ & $\begin{array}{l}\text { F-ratio } \\
5.28 * *\end{array}$ \\
\hline
\end{tabular}

Due to the regular and intense fertilization, the soil became acidified and its microbiological consequences were the increase in the number of microscopic fungi and the decrease of the number of nitrifying bacteria (Helmeczi et al., 1987; Khonje et al. 1989). The large doses of fertilizers were not only able to decrease the number and activity of soil bacteria (Zvyagintsev, 1987), but also the number of genus of soil fungi too (Kátai et al., 1983). In the course of soil microbiological examinations a large number of soil bacteria (total bacteria, $\mathrm{N}_{2^{-}}$ fixing, nitrifying and cellulose decomposing bacteria) were observed in near-neutral and slightly alkaline $\mathrm{pH}$, but fewer fungi (Zsuposné, 2007). According to the data of literature and our other results the application of adequate quantity of lime can restore the soil biological balance (Vágó et al., 2008, Tolner et al., 2008).

Concerning the biological activity of soil, the phosphatase, urease, saccharase, catalase and dehydrogenase activities were determined. The activity of phosphatase was lower in July than in September. The enzyme activity increased compared to the control, but it was not accordance with the doses of fertilizer. Regarding urease activity, the results were unambiguous in the soil samples in July, but in September, the activity values increased simultaneously with the fertilizer doses. Concerning saccharase and catalase activities there was no remarkable difference between the results obtained at different times. Both enzymes' activities showed decreasing tendencies with the increasing doses of fertilizers. The dehydrogenase activity was higher in July, so it seemed that the increasing doses of fertilizers stimulated the activity. In September, the enzyme activities were lower and there were minor differences between the treatments.

On the whole, it can be stated that the effects of fertilizers were favourable to the activities of phosphatase, urease, and dehydrogenase, while with the increasing doses of fertilizers, the activities of saccharase and catalase gradually decreased. 
The effects of fertilization on some enzyme activities (Debrecen - Látókép, 2008)

\begin{tabular}{|c|c|c|c|c|c|c|}
\hline \multicolumn{2}{|r|}{ Treatments } & $\begin{array}{l}\text { Phosphatase } \\
\mathrm{mg} \mathrm{P}_{2} \mathrm{O}_{5} \cdot 100 \mathrm{~g}^{-1}\end{array}$ & $\begin{array}{c}\text { Urease } \\
\mathrm{mg} \mathrm{NH}_{4}-\mathrm{N} \cdot 100 \mathrm{~g}\end{array}$ & $\begin{array}{c}\text { Saccharase } \\
\mathrm{mg} \text { glucose } \cdot 100\end{array}$ & $\begin{array}{c}\text { Catalase } \\
\mathrm{ml}_{2} \cdot 2 \mathrm{~min}^{-1} \cdot 2 \mathrm{~g}^{-1}\end{array}$ & $\begin{array}{c}\text { Dehydrogenase } \\
\mu \mathrm{g} \text { INTF } \cdot \mathrm{g}^{-1} \text { dwt soil }\end{array}$ \\
\hline \multirow[t]{2}{*}{1} & July & 14.43 & 20.50 & 19.85 & 21.7 & 62.1 \\
\hline & September & 20.89 & 15.67 & 17.74 & 19.3 & 47.1 \\
\hline \multirow[t]{2}{*}{2} & July & 19.96 & 21.79 & 20.66 & 20.0 & 63.1 \\
\hline & September & 23.66 & 17.64 & 18.52 & 17.0 & 46.8 \\
\hline \multirow{2}{*}{3} & July & 17.22 & 20.93 & 19.68 & 18.3 & 85.4 \\
\hline & September & 25.44 & 26.01 & 18.23 & 16.0 & 51.2 \\
\hline \multirow{2}{*}{4} & July & 16.71 & 17.50 & 13.97 & 15.0 & 74.2 \\
\hline & September & 24.91 & 28.59 & 13.48 & 13.0 & 47.4 \\
\hline \multirow{5}{*}{ V } & July & 15.19 & 23.29 & 12.17 & 13.0 & 80.3 \\
\hline & September & 26.43 & 33.49 & 13.97 & 12.0 & 66.7 \\
\hline & $\operatorname{LSD}_{5 \%}$ & 1.883 & 4.066 & 1.442 & 1.302 & 5.479 \\
\hline & iance analysis & F-ratio & F-ratio & F-ratio & F-ratio & F-ratio \\
\hline & 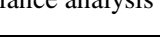 & $5.90 * *$ & $4.80 * *$ & $32.92 * * *$ & $44.59 * * *$ & $15.42 * * *$ \\
\hline
\end{tabular}

\section{CONCLUSIONS}

In a long term fertilization experiment in Látókép of UD, CAAES, the effects of a 25-year-long fertilization were examined in calcareous chernozem soil. In a block fertilized (maize triculture) we studied the effects of different fertilizer doses on the physical, chemical and microbial features. The results are as follows:

- The moisture content of soil was substantial at both sampling times. According to the silt and clay contents, as well as the Arany-type plasticity index, the soil had loam texture.

- Due to the increasing doses of fertilizers, the $\mathrm{pH}$ in distilled water and in $1 \mathrm{M} \mathrm{KCl}$ decreased significantly.

- Simultaneously, the hydrolytic acidity doubled in July and September too.

- Based on the results, it is evident that - with substantial moisture content - the nutrient uptake of plants was tremendous between July and September, which was proven by the smaller quantity of nutrients in the soil in September. At the same time the effects of the treatments were unambiguous.

- Due to the medium-large and large doses of fertilizers the number of soil bacteria decreased but the number of microscopic fungi increased. These changes can be proven by the bacteria-fungi ratio in soil.

- According to the results of the 25-year-long fertilization experiment, soil acidification had soil microbiological consequences as the manifestation of stress effect.

- The numbers of nitrifying and cellulose decomposing bacteria decreased by the effect of large doses of fertilizers. In the case of nitrifying bacteria the „resistant stage" changed into ,exhaustion stage” by the stress effect.

- The effects of fertilization were positive on the activities of phosphatase, urease and dehydrogenase, but in contrast with it, the activities of saccharase and catalase showed decreasing tendencies with the increasing doses of fertilizers.

\section{ACKNOWLEDGEMENTS}

We say many thanks to Professor Péter Pepó, director of institute, for the opportunity to get soil samples from the long term fertilization experiment of Debrecen Látókép Research Station. 


\section{REFERENCES}

Andrejuk, E. I. 1990. Soil biotechnology and intensive agricultural production in soils of the Southern Ukraine. Agrokémia és Talajtan. 39. 3-4. 412-414.

Avdonyin N, Sz.: 1972. Savanyú talajok termékenységének fokozása. Mezőgazdasági Kiadó. Bp. 91-93.

Blaskó L. - Debreceni B-né - Holló S. - Kadicskó B. - Sárvári M. Mütrágyázás, talajsavanyodás és meszezés összefüggései az OMTK kísérlethálózat talajain. OMTK Hálózati Tanács, Kompolt-Karcag. 236.p.

Bocz E. 2001. A talajtermékenység növénytermesztéstani fogalma és növelhetőségének feltételrendszere. In „Integrációs feladatok a hazai növénytermesztésben” II. Növénytermesztési Tudományos Nap. Proceedings Bp. 13-17. P.

Buzás, I. (ed.): 1988. Methods of soil and agricultural chemisty analyses 2. Physical-chemical and chemical methods of soil analyses. (In Hungarian) Mezőgazdasági Kiadó. Bp. 90-93.

Felföldy L. 1987. A biológiai vízminősítés. (4. Javított és bővített kiadás.) Bp. 172-174. P.

Filep, GY., 1988. Talajvizsgálat. Egyetemi jegyzet. Debrecen. 105-107.

Frankenberger, W.T. \& Johanson, J.B., 1983. Method of measuring invertase activity in soils. Plant and Soil. 74., 301-311.

Füleky, Gy.: 2008. Results of a 30-year-old fertilization experiment. Acta Agronomica Hungarica, 56: 3. 265-273.

Gerei L. (szerk.) Talajtani és agrokémiai módszerek. OMMI Kiadvány 16-19. P.

Gulyás F. 1985. A foszfor- és káliumtrágyázás talajbiológiai hatásai. In: A mezőgazdaság kemizálásának talajbiológiai kérdései. (ed. Tóth B.) MTA Veszprémi Akad. Biz. Monográfiája, 33-52.

Helmeczi, B. - Kátai, J. - Nagy, M. - Oláh Zsupos, A.: 1987. The effect of acidification on soil microorganisms Proceedings of the $9^{\text {th }}$ Int. Symposium on Soil Biology and Conservation of the Biosphere, Vol. 2. (ed. J, Szegi), Bp. Akad. Kiadó. 777-791.

Kádár I. - Márton L. - Németh T. - Szemes I.: 2007. Meszezés és mütrágyázás hatása a talajra és növényre a 44 éves nyírlugosi tartamkísérletben. Agrokémia és Talajtan 56: 2. 255-270.

Kátai, J. - Helmeczi, B. - Bessenyei, M. - Nagy, M.: 1983. Effect of irrigation and fertilization on the microscopic fungi of the soil. Proceedings of the $8^{\text {th }}$ Int. Symposium on Soil Biology and Conservation of the Biosphere, (ed. J, Szegi), Bp. Akad. Kiadó. 133-143.

Kátai, J.: 2006. Changes in soil characteristics in a mono- and triculture long term experiment. Agrokémia és Talajtan, 55: 1. $183-192$.

Kátai, J. 1997. The effect of agrotechnical methods on microflora and biological activity in the soil. In: Land Use and Soil Management. 911. Dec. 1996. (ed. Gy. Filep) 240-252.

Kátai J. 1999. Talajmikrobiológiai jellemzők változása trágyázási tartamkísérletben. Agrokémia és Talajtan. 48/3-4., 348-358. P.

Kátai J. \& Helmeczi B. 1995.: A műtrágyázás és a vetésváltás hatása a talaj mikrobiológiai folyamataira. A Debreceni Agrártudományi Egyetem Tudományos Közleményei XXXI. 169-177. P.

Lásztity B., Kádár I. \& Gulyás F. 1981. Mútrágyázás hatása néhány talaj cellulózbontó aktivitására. Agrokémia és Talajtan. 30. 1-2. 91-98. Mersi, W. (1996): Dehydrogenase Activity with the Substrate INT In: Schinner, F. - Öhlinger, R. - Kandeler, E. - Margesin, R. Methods in soil biology. Springer-Verlag Berlin Heidelberg. 243-245.

Khonje, D. J. - Varsa, E. C. - Klubek, K.: 1989. The acidulation effects of nitrogenous fertilizers on selected chemical and microbiological properties of soil. Communications in Soil Science and Plant Analysis. 20: 13-14. 1377-1395.

Pepó P. \& Nagy J. 1997. Plant Nutrition System of Cereals in Their Sustainable Crop Production. Agrokémia és Talajtan. 1-4., 113-126. Pochon, J. - Tardieux, P.: 1962. Techniques D'analyse en microbiologie du sol. Collection “Technivues de Base". Editions de la Tourelle. St. Mandé.102.

Rékási M. - Filep T. : 2007. A talajok sav-bázis pufferkapacitásának értékelésére alkalmas módszer vizsgálata. Agrokémia és Talajtan, 56 : 2. 29-38.

Rékási M. 2008. Talajtulajdonságok hatása a protonátmenettel járó felületi reakciók kinetikájára. Agrokémia és Talajtan, 57: 2. 281-292.

Sárvári M. \& Szabó P. 1998 A termesztési tényezők hatása a kukorica termésére. Növénytermesztés. 1998. 47., 2. 213-221. P.

Simon, B. - Tolner, L. - Rékási, M. - Michéli, E.: 2006. Soil acidity by potentiometric titrations. Cereal Research Communication, $34: 1$. 283-286.

Szegi, J.: 1979. Methods for Soil Microbiological Analysis. (In Hungarian) Mezőgazdasági Kiadó. Bp. 49.

Tolner, L. - Vágó, I. - Czinkota, I. - Rékési, M. - Kovács, Z.: 2008: Field testing of a new, more efficient liming method. Cereal Research Communications Vol. 36. 1. 543-546.

Vágó, I. - Tolner, L. - Eichler-Löbermann, B. - Czinkota I. - Kovács B.: 2008 The long-term effects of liming on the dry matter production and chemical composition of perennial ryegrass (Lolium perenne L.). Cereal Research Communications Vol. 36. 1. 103-106.

Várallyay, Gy.: 2006. Soil degradation processes and extreme soil moisture regime as environmental problems in the Carpathian Basin. Agrokémia és Talajtan, 55: 1. 9-18.

Virág Á. 1981. A mezőgazdasági kemizálás környezetvédelmi összefüggései. Mg. Kiadó. Bp. 55-57.

Zvyagintsev, D. G.: 1987. Effect of mineral fertilizers on microbiological processes in the soil. Proceeding of the $9^{\text {th }}$ Int. Symposium on Soil Biology and Consevation of the Biosphere, Vol. 1. (ed. J, Szegi), Bp. Akad. Kiadó. 3-13.

Zsuposné, O. Á.: 2007. Changes of biological activity in different soil types. Cereal Research Communication, 35: 2. 861-864. 